\title{
Comparison of chemical contents and in vitro nutrient digestibility of maize stalks from high oil maize with conventional or specific fodder maize*
}

\author{
G.L Yan ${ }^{1,2}$, J.X. Wang ${ }^{3}$, C.M. Cao' ${ }^{2}$ H.S. Xin'1, L. Wan ${ }^{1}$ \\ and Q.X. Meng ${ }^{1,4}$ \\ ${ }^{1}$ College of Animal Science and Technology, China Agricultural University \\ Beijing 100094, P.R. China \\ ${ }^{2}$ Animal Husbandry and Engineering Department, Hebei North College \\ Zhangjiakou 075131, P.R. China \\ ${ }^{3}$ Department of Animal Health, Ministry of Agriculture \\ Beijing 100026, P.R. China
}

\section{ABSTRACT}

Maize stalks of five cultivars, namely two high oil maize (HOM: HOM 647 and HOM 298), two conventional maize (CM: CAU 80 and CAU 3138) and a fodder maize (FM: Qingsi \#1), were selected to examine the effect of maize cultivars on chemical composition and in vitro digestibility of their stalks. The result showed that HOM stalks had higher nutrient contents and higher digestibility of dry matter and neutral detergent fibre than CM stalks and FM stalks. Gas production of HOM stalks was greater than that of CM or FM stalks at each time point during $120 \mathrm{~h}$ in vitro incubation.

KEY WORDS: maize stalks, maize cultivars, chemical composition, in vitro digestibility, gas production

\section{INTRODUCTION}

High oil maize (HOM) is a new cultivar of maize, which kernels yield not only higher oil but also more proteins, especially essential amino acids such as lysine and methionine, vitamin $\mathrm{A}$ and $\mathrm{E}$, and other nutrients than those in conventional maize $(\mathrm{CM})$. There were a few published reports on HOM stalks, which mainly

\footnotetext{
* Supported in part by grants from National Outstanding Young Scientist Foundation, Grant No. 30125033 and National Natural Science Foundation of China, Grant No. 30270944

${ }^{4}$ Corresponding author: e-mail: qxmeng@cau.edu.cn
} 
dealt with the proximate analyses and HOM silage feeding experiments (Atwell et al., 1988; LaCount et al., 1995; Weiss and Wyatt, 2000). In China, the HOM cultivars usually have average kernel oil contents at more than $8 \%$. In some cultivars, such as HOM 298, their oil contents of grains were over $10 \%$ (Chen, 2001). Furthermore, the HOM cultivars possess a favourite characteristic, e.g., maintenance of green colour in their stalks for long duration at the kernel milk line stage of complete maturity (Song, 2001). Based on these characteristics, HOM cultivar stalks appeal to an ideal fodder to dairy and beef cattle and other ruminant livestock. Therefore, in the present experiment, comparisons were made of chemical composition and in vitro digestibility of maize stalks from high oil maize with conventional or specific fodder maize.

\section{MATERIAL AND METHODS}

The maize cultivars including two high oil maize (HOM 647 and HOM 298), two of conventional maize (CM; CAU 80 and CAU 3138) and one fodder maize (FM; Qingsi \#1), which were formally bred at The National Maize Improvement Centre of China, were planted in the experimental field of China Agricultural University, Chang Ping Experimental Station, in 2003. The experimental field was prepared for identical soil type, fertilizer administration, water supply and other climatic conditions. The stalk samples were collected according to the maturity stage in September of 2003. Maturity stages were defined as $1 / 2,3 / 4$ and $4 / 4$ milk line (ML) based on the position of ML in maize kernels. Considering optimum harvesting time schedules of the five different maize cultivars, the samples of HOM stalks and CM stalks were actually taken at 4/4 ML stage and the sample of FM at 3/4 ML stage. Each cultivar sample consisted of whole stalks from 10 plants.

The air dried whole maize stalks were ground to through $1.5 \mathrm{~mm}$ size screen using a Perten Laboratory Mill (Model 3100, Sweden), homogenized and analysed for the contents of dry matter (DM), ether extract (EE), crude protein (CP), crude ash, $\mathrm{Ca}$, and $\mathrm{P}$ by AOAC procedures (1990). Neutral detergent fibre (NDF), acid detergent fibre (ADF) and lignin were measured following the methods of Van Soest et al. (1991). Neither alpha amylase nor sodium sulphite was used in the NDF procedures. The content of sugar and starch was analysed with an enzymatic digestion procedure (Xiong et al., 1990) using amyloglucosidase (Sigma Cat. No. A-7255) to digest substrate sugars. Water soluble carbohydrates (WSC) was also determined with the above enzyme procedure (Xiong et al., 1990) with a minor modification that sample substrates were not treated with amyloglucosidase and gelatinization, but allowing substrates in the buffer solution tube to vibrate for 60 min, then filtrates were compared for chromatographic values. Starch content was calculated by subtracting WSC from the total sugar and starch. 
In vitro digestibilities of DM, NDF and ADF (IVDMD, IVNDFD, IVADFD) were determined according to the procedures of Tilley and Terry (1963) with a minor modification. Namely, the ground stalk samples, weighed into specialized non-woven fabric bags and put into fermentation tubes, were anaerobically incubated with buffer-rumen fluid mixture solution in a water bath at $39^{\circ} \mathrm{C}$ for 48 $\mathrm{h}$, shaking twice a day routinely. The rumen fluid was obtained from 3 Holstein steers fitted with a permanent rumen fistula, which were fed a formulated ration of $30 \%$ roughages ( $1 / 3$ dehydrated lucerne and $2 / 3$ dry maize stalks) and $70 \%$ mixed concentrates. At the end of first phase of incubation ( $48 \mathrm{~h}$ ), the fabric bags were removed from the tubes and aerobically incubated for further $48 \mathrm{~h}$ with pepsin solution $(0.2 \%$ pepsin dissolved in $0.1 \mathrm{~N} \mathrm{HCl}$ to achieve a final pepsin activity of $1: 10,000)$. After incubation, the samples were analysed for residual DM, NDF and ADF to calculate IVDMD, IVNDFD and IVADFD.

The in vitro gas production of the fermentation of the maize stalks was measured according to the method of Menke and Steingass (1988). Briefly, $200.0 \mathrm{mg}$ of dry sample (substrate) were weighed into $100 \mathrm{ml}$ special calibrated glass syringes, adding $30 \mathrm{ml}$ of anaerobic buffer-rumen fluid mixture solution, and incubated at $39^{\circ} \mathrm{C}$ for $120 \mathrm{~h}$ in an incubator equipped with a rotor. The gas production was measured at the time intervals of $1,2,3,4,5,6,8,10,12,16,20,24,28,32,36$, $40,44,48,56,64,72,80,88,96,104,112$ and $120 \mathrm{~h}$, respectively.

The experiment was designed in a randomly factorial design. All data collected were presented on a DM basis and were subjected to analyse the variance using the General Linear Models procedure of SAS (1999).

\section{RESULTS}

Chemical composition of three maize stalks was shown in Table 1. There were significant $(\mathrm{P}<0.002)$ differences among three cultivars of maize stalks. HOM stalks had highest contents of readily digestible components (such as WSC, starch, EE and CP) and lowest contents of less digestible components (such as NDF and ADF). The average contents of WSC, starch and EE in HOM stalks were measured as, \%: 21.8, 5.2 and 2.8, respectively, which were 19.8 folds $(21.8$ vs $1.1 \%$; $\mathrm{P}<0.001), 3.5$ folds (5.2 vs $1.5 \%$; $\mathrm{P}<0.001), 2.0$ folds (2.8 vs $1.4 \%$; $\mathrm{P}<0.001)$ as much as that of CM stalks. Meanwhile, the average contents of NDF, ADF and lignin in HOM stalks were, \%: 57.7, 34.5 and 4.7, respectively, which were by $27.3 \%$ ( 57.7 vs $79.4 \%$; $\mathrm{P}<0.001$ ), $32.0 \%$ (34.5 vs $50.7 \%$; $\mathrm{P}<0.001$ ) and by $39.7 \%$ ( 4.7 vs $7.8 \%$; $\mathrm{P}<0.001)$ lower than that of $\mathrm{CM}$ stalks. The average contents of WSC, starch and EE in HOM stalks were higher than FM stalks by $246.0 \%$ (21.8 vs $6.3 \% ; \mathrm{P}<0.001), 108.0 \%$ (5.2 vs $2.5 \% ; \mathrm{P}<0.003)$ and $33.1 \%$ (2.8 vs $2.1 \%$; $\mathrm{P}<0.012$ ), respectively. Moreover, the average contents of NDF, ADF and lignin 
were lower than these of FM stalks by $17.3 \%$ (57.7 vs $69.8 \%$; $\mathrm{P}<0.001), 18.8 \%$ (34.5 vs $42.5 \% ; \mathrm{P}<0.001$ ) and $31.9 \%$ (4.7 vs $6.9 \% ; \mathrm{P}<0.001$ ), respectively. As to minerals, the content of crude ash in HOM stalks was lower $(\mathrm{P}<0.001)$ than that of CM stalks or FM stalks; HOM stalks had higher P content $(0.13$ vs $0.07 \%$; $\mathrm{P}<0.001)$ but lower Ca content $(0.43$ vs $0.60 \% ; \mathrm{P}<0.001)$ than $\mathrm{CM}$ stalks.

Table 1. Effect of maize cultivars on major chemical components of maize stalks

\begin{tabular}{|c|c|c|c|c|c|c|c|c|c|}
\hline \multirow{2}{*}{$\begin{array}{l}\text { Item } \\
\% \mathrm{DM}\end{array}$} & \multicolumn{2}{|c|}{ HOM } & \multicolumn{2}{|c|}{$\mathrm{CM}$} & \multirow[b]{2}{*}{ FM } & \multirow[b]{2}{*}{ SEM } & \multirow[b]{2}{*}{$P$ value } & \multicolumn{2}{|c|}{ Contrast, $\mathrm{P}=$} \\
\hline & HOM298 & HOM647 & CAU80 & CAU3138 & & & & $\begin{array}{c}\mathrm{HOM} \\
\text { vs CM }\end{array}$ & $\begin{array}{c}\text { HOM } \\
\text { vs FM }\end{array}$ \\
\hline$\overline{\mathrm{DM}}$ & 35.38 & 35.15 & 62.19 & 70.42 & 28.57 & 3.16 & $<0.001$ & $<0.001$ & 0.044 \\
\hline WSC & 24.3 & 19.2 & 1.3 & 0.9 & 6.3 & 0.21 & $<0.001$ & $<0.001$ & $<0.001$ \\
\hline Starch & 4.8 & 5.5 & 1.4 & 1.5 & 2.5 & 0.59 & 0.001 & $<0.001$ & 0.002 \\
\hline $\mathrm{EE}$ & 2.9 & 2.7 & 1.5 & 1.2 & 2.1 & 0.20 & $<0.001$ & $<0.001$ & 0.011 \\
\hline $\mathrm{CP}$ & 6.1 & 7.0 & 6.4 & 6.0 & 7.6 & 0.12 & 0.001 & 0.321 & 0.019 \\
\hline Ash & 5.6 & 6.2 & 8.1 & 7.3 & 8.0 & 0.05 & $<0.001$ & $<0.001$ & $<0.001$ \\
\hline $\mathrm{Ca}$ & 0.43 & 0.43 & 0.60 & 0.54 & 0.40 & 0.01 & $<0.001$ & $<0.001$ & 0.346 \\
\hline $\mathrm{P}$ & 0.09 & 0.16 & 0.07 & 0.06 & 0.12 & 0.01 & $<0.001$ & 0.001 & 0.701 \\
\hline NDF & 56.7 & 58.7 & 79.0 & 79.8 & 69.8 & 0.17 & $<0.001$ & $<0.001$ & $<0.001$ \\
\hline $\mathrm{ADF}$ & 34.4 & 34.6 & 49.6 & 51.7 & 42.5 & 0.14 & $<0.001$ & $<0.001$ & $<0.001$ \\
\hline Lignin & 4.6 & 4.7 & 7.0 & 8.5 & 6.9 & 0.09 & $<0.001$ & $<0.001$ & $<0.001$ \\
\hline
\end{tabular}

As shown in Table 2, in vitro digestibilities of DM and fibrous fractions were significantly $(\mathrm{P}<0.001)$ different among stalks of three cultivars. HOM stalks were

Table 2 Effect of cultivars on the in vitro digestibility of dry matter and fibrous fractions of maize stalks

\begin{tabular}{|c|c|c|c|c|c|c|c|c|c|}
\hline \multirow{2}{*}{$\begin{array}{l}\text { Item } \\
\% \mathrm{DM}\end{array}$} & \multicolumn{2}{|c|}{ HOM } & \multicolumn{2}{|r|}{$\mathrm{CM}$} & \multirow[b]{2}{*}{ FM } & \multirow[b]{2}{*}{ SEM } & \multirow[b]{2}{*}{$P$ value } & \multicolumn{2}{|c|}{ Contrast, $\mathrm{P}=$} \\
\hline & HOM298 & HOM647 & CAU80 & CAU3138 & & & & $\begin{array}{c}\mathrm{HOM} \\
\text { vs CM }\end{array}$ & $\begin{array}{c}\text { HOM } \\
\text { vs FM }\end{array}$ \\
\hline IVNDFD & 49.2 & 48.4 & 40.4 & 40.0 & 45.5 & 0.55 & $<0.001$ & $<0.001$ & $<0.001$ \\
\hline IVADFD & 45.4 & 45.0 & 37.3 & 34.7 & 43.1 & 1.08 & $<0.001$ & $<0.001$ & 0.161 \\
\hline IVDMD & 68.2 & 66.8 & 48.4 & 49.1 & 58.6 & 0.42 & $<0.001$ & $<0.001$ & $<0.001$ \\
\hline
\end{tabular}

higher $(\mathrm{P}<0.001)$ than $\mathrm{CM}$ stalks in IVDMD, IVNDFD and IVADFD, which on average were increased by $38.3 \%$ (67.5 vs $48.8 \%), 21.4 \%$ (48.8 vs $40.2 \%)$ and $25.6 \%$ (45.2 vs $36.0 \%$ ), respectively. IVDMD and IVNDFD in HOM stalks were also higher $(\mathrm{P}<0.001)$ than FM stalks, enhanced by $15.2 \%(67.5$ vs $58.6 \%)$ and $7.3 \%$ ( 48.8 vs $45.5 \%)$, respectively. 


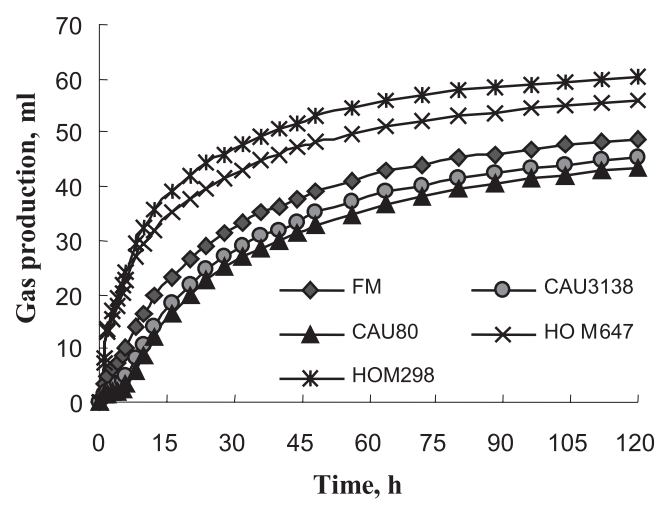

Figure 1. Effect of cultivars on in vitro gas production (ml/0.200 g DM) of maize stalks

The results of gas production rate are presented in Figure 1. Gas production had significant $(\mathrm{P}<0.001)$ differences among the three cultivars of maize stalks at all time points during incubation. Gas production of HOM stalks was not only greater $(\mathrm{P}<0.001)$ at all the time points than that of $\mathrm{CM}$ stalks, but also greater $(\mathrm{P}<0.001)$ than that of FM stalks, being enhanced by $80.3 \%$ (42.0 vs $23.3 \mathrm{ml})$ and $51.8 \%$ (50.7 vs $33.4 \mathrm{ml}$ ) for HOM stalks than those of CM stalks at 24 and $48 \mathrm{~h}$, respectively; and $45.8 \%$ (42.0 vs $28.8 \mathrm{ml}$ ) and $29.3 \%$ (50.7 vs $39.2 \mathrm{ml}$ ) than those of FM stalks.

\section{DISCUSSION}

Generally, as maturity of kernels advanced, the content of fibrous fraction in stalks was increased, while the digestibility was decreased. Harvest of conventional maize grains is usually accepted at $4 / 4 \mathrm{ML}$ stage of kernels, but at this stage the stalks of CM have become dried over with poor nutritive value. In contrast, harvest of HOM grains at 4/4 ML stage produces not only larger yield of grains but also higher nutritional levels of by-product (stalks). The gas productions were significantly $(\mathrm{P}<0.001)$ higher for HOM stalks than CM and FM stalks, which is highly consistent with the higher contents of readily digestible components (such as WSC, starch, EE and $\mathrm{CP}$ ) and lower contents of less digestible components (such as NDF and ADF) for HOM stalks than CM and FM stalks. The present study clearly suggests that the HOM can represent a favourable cultivar for ruminant feeding because of not only high oil grains but also great nutritive value of stalks probably used for making good silages. Similar to this result, Zhao (2003) also obtained a higher nutritive value in another variety of high oil maize stalks (HOM 115) relative to traditional maize stalks. 


\section{CONCLUSIONS}

Because of high contents of nutrients and high in vitro digestibility of DM and NDF, high oil maize cultivar stalks appeal a great potential to be utilized as a fodder or ensilage source for ruminant feeding.

\section{REFERENCES}

AOAC, 1990. Association of Official Analytical Chemists, Official Methods of Analysis. 15th Edition. Arlington, VA

Atwell D.G., Jaster E.H., Moore K.J., Fernando R.L., 1988. Evaluation of high oil corn and maize silage for lactating cows. J. Dairy Sci. 71, 2689-2698

Chen S.J., 2001. Today, past and tomorrow of high oil corn (in Chinese). Corn Sci. 9 (4), 80-83

LaCount D.W., Drackley J.K., Cicela T.M., Clark J.H., 1995. High oil corn as silage or grain for dairy cows during an entire lactation. J. Dairy Sci. 78, 1745-1754

Menke K.H., Steingass H., 1988. Estimation of the energetic feed value obtained from chemical analysis and in vitro gas production using rumen fluid. Anim. Res. Develop. 28, 7-55

SAS, 1999. SAS/STAT software. Release 8.0. SAS Institute Inc. Cary, NC

Song T.M., 2001. Welcome the new century of high oil corn (in Chinese). Sci. Technol. Seeds (5), 279-281

Tilley J.M.A., Terry R.A., 1963. A two stage technique for the in vitro digestion of forage crops. J. Brit. Grassl. Soc. 18, 104-111

Van Soest P.J., Robertson J.B., Lewis B.A., 1991. Methods for dietary fiber, neutral detergent fiber, and nonstarch polycarbohydratess in relation to animal nutrition. J. Dairy Sci. 74, 3583-3597

Weiss W.P., Wyatt D.J., 2000. Effect of oil content and kernel processing of corn silage on digestibility and milk production by dairy cows. J. Dairy Sci. 83, 351-358

Xiong Y., Bartle S.J., Preston R.L., 1990. Improved enzymatic method to measure processing degree and availability of starch in sorghum grain. J. Anim. Sci. 68, 3861-3870

Zhao Z.Y., 2003. Interation between variety and maturity stage of kernels to affect silage fermentation characteristics of high oil corn stalks and their feeding value to growing cattle (in Chinese). Master's Degree Thesis, China Agricultural University, Beijing (P.R. China) 